\title{
IMPLEMENTATION OF PROJECT MANAGEMENT MATURITY MODEL TO IMPROVE THE EFFICIENCY OF ACTIVITY OF LOCAL SELF-GOVERNMENTS
}

\author{
Oleksandra Niema \\ Lviv Regional Institute of Public Administration of the National Academy of Public \\ Administration under the President of Ukraine, Ukraine
}

\begin{abstract}
In the conditions of growing demands of society to the government, project activities cover not only traditional industries, but also the sphere of public administration. Critically important for the success of organization is the team (rather than individual) level of knowledge, skills of staff, and a certain maturity of the organization as a whole in the field of project management. However, the project activities of local self-governments cannot be considered effective or fully compliant with the modern requirements. The level of project competence of management teams of many territorial communities is still not sufficient for the implementation of tasks and functions, the production of relevant project ideas and their successful implementation. The aim of the research is to describe of project management maturity model for its implementation into the activities of the local self-governments from the positions of effectiveness of project management. The entry of the local self-government to a high level of project management maturity will reduce the negative impact of the human factor, systematically focus activities on meeting the needs of the community on a project basis, improve the quality of project management processes, and reduce unproductive costs. Methods used - analysis and synthesis, induction and deduction, logical generalization and comparison.
\end{abstract}

Keywords: local self-government, management maturity level, maturity models, project competence, project management maturity model.

\section{Introduction}

The territorial authorities organization and local self-government decentralization reform is reasonably called one of the most successful reforms in Ukraine since 2014. Its effectiveness resulted from a synergy of efforts taken by public authorities and citizens, secured by the organizational and financial participation of international partners of the country. Its support among the population today is the Ukrainian national trend, which is evidenced by many sociological studies. The main achievements of the reform are the increase of capability of the joint territorial communities (territorial communities) to 
Niema, 2021. Implementation of Project Management Maturity Model to Improve the Efficiency of Activity of Local Self-Governments

develop their territories, to create modern educational, medical, transport, housing and utilities infrastructure, to provide residents with quality and affordable services. Capable communities possessing tools, opportunities and resources to ensure complete (sustainable) local development are the foundation of a strong state.

In the conditions of growing demands of society to the government, which require the search and implementation of effective mechanisms for resolving contradictions between private and public interests, public and government opinion, individual and managerial approaches to solving urgent problems, the project activities cover not only traditional spheres of production but also the sphere of public administration. After all, the implementation of public policy is carried out through the targeted intervention of public authorities and local self-government bodies in the existing social practice. Such intervention is aimed at changing the behaviour of social groups (target groups) that caused the problem and can take place not only in the format of development and adoption of regulatory instruments but also in the form of programs or projects.

The analysis of the international experience of project activities shows that in many developed countries of the world the important tasks set before the local self-government bodies include the direction of activities to the search extrabudgetary alternative sources of financing and establishing cooperation with the international funds, programs and grants, active participation in project competitions and their successful implementation, an effective problem solving through project management. This requires adaptation and formalization of project management processes with the consideration of the specific nature of the activity of the local self-government bodies, the introduction of appropriate project management tools, the formation and development of project competencies of local managers. In project management to assess the organizations' development level in the field of project activities are used the project maturity models.

The aim of the research is to describe of project management maturity model for its implementation into the activities of the local self-governments from the positions of effectiveness of project management. Formation of an approach to project management maturity level assessment of local governments is possible on the basis of generalization of existing of project maturity models and taking into account the specific features of activities of self-government bodies.

The research used general scientific and special methods, in particular: analysis and synthesis, induction and deduction, logical generalization and comparison. 


\section{Main Text}

The use of projects as a tool for the implementation of strategic goals to develop territorial communities allows to attract additional resources (funds from the state budget allocated for the development of territorial communities and grants allocated by other financial institutions and investors for the execution of the projects, selected on a competitive basis) and carry out a series of projects for the implementation of strategic initiatives.

However, the project activities of local self-government bodies cannot be considered effective or such that fully meet the present-day requirements. The level of project competence of management teams of many territorial communities is still not sufficient for the implementation of the assigned tasks and functions, the production of relevant project ideas and their successful implementation.

In particular, the selection of the projects by the State Fund for Regional Development on a competitive basis for the implementation of the government grant to develop the joint territorial communities infrastructure in Ukraine provides evidence of the poor quality of projects, which has been repeatedly emphasized by experts at various levels. This situation is also caused by the problems of methodological support of project activities in local selfgovernment bodies.

Business experience confirms that the level of team's (but not individual) knowledge and personnel skills, in other words, a kind of the entire organizational maturity in the sphere of project management is critically important for the success of a market organization. A long time ago, business structures have realized the dependence of their market success on the ability of the staff to develop and implement projects. Specialized project maturity models have emerged. With the help of such models it is possible to assess the organization overall development level in the field of project activities to identify the ways for its further improvement (Ushakova \& Sharov, 2018); reveal strengths and weaknesses, explore the level of quality of performance, management and control over corresponding processes, assess the degree of readiness of local self-government body for the effective management of its activity and development based on a project approach (Bezuhlyi \& Sharov, 2015).

The project management maturity models are a set of parameters that correspond to a specific stage of the project development of any organization (Dziubina, 2010). They formalize the scheme and conditions with a help of which the company will methodically and purposefully achieve the excellence in project management (Malinina, 2011). 
Niema, 2021. Implementation of Project Management Maturity Model to Improve the Efficiency of Activity of Local Self-Governments

The concept of project management maturity has been actively developing since 2001 (Cooke-Davies, Schlichter, \& Bredillet, 2001). In their works K. Grant and J. Pennypacker speak about 30 models of organizational maturity in various aspects (Grant \& Pennypacker, 2006), new models of project management maturity continue to appear. Among them are simple and very complex models. They differ in appraisal ratios of the current state of the organization in the field of project management and the number of levels of project maturity. However, these models have many common features, in particular, the step-by-step concept of transition from a lower level of the project management maturity processes to a higher one. The above-mentioned concept provides for continuous improvement of the project management system and the project management maturity models include the knowledge of such management tools. They take into account the transfer of the best experience and staff development, are focused on the optimization of business processes, as well as the formation of a common methodology for project management development.

The following are the most common organizational project maturity assessment models in international practice:

- Project Management Maturity Model (PMMM/PM3) was developed in 2002 by H. Kerzner. The model focuses on the development stage of project management practices and consists of five levels: level 1 - Common Language (Initial Process), 2 - Common Processes (Repeatable Process), 3 - Singular Methodology (Defined Process), 4 - Benchmarking (Managed Process), 5 Continuous Improvement (Optimized Process). PM3 contains the characteristics of each maturity level, describes possible risks and measures, necessary to transfer from lower level to higher one (Kertsner, 2003). The model provides for a quantitative assessment of definite values with further identification of conformity between the sum of gained scores and definite maturity level in the project management.

- Organizational Project Management Maturity Model (OPMMM/OPM3) is the international standard, developed in 2003 by the Project Management Institute (PMI). It includes the base of the best practices, structured according to three management objects (project, program, project portfolio). OPM3 consists of the following interconnected elements: knowledge and experience related to the project management (best practices), which characterize the appropriate levels of organizational maturity; the mechanism of assessing the organizational maturity level; the ways to increase the organizational maturity level.

This model is aimed to provide a continuous assessment of maturity in two main dimensions. One of them includes the management objects and organizational mechanisms and another - the maturity levels (Standardize, Measure, Control and Continuous Improvement). On the one hand, OPM3 
allows to evaluate the project management maturity level of own organization, and on the other hand, to use the base of the best practices as a guide to define the current level and assure the further development (PMI, 2013).

- Portfolio, Programme and Project Management Maturity Model (P3M3) was developed in 2003 by the UK Department of State for Trade Policy, first of all, to improve the index of state sector organizations (OGC, 2010). Model is based on identifying the strengths and weaknesses of the organization in seven process areas: management control, benefits management, financial management, stakeholder management, risk management, organizational management and resource management.

P3M3 is complex and consists of three models: Portfolio Management Maturity Model (PfM3); Program Management Maturity Model (PgM3) and Project Management Maturity Model (PjM3). The organization independently chooses one or more of them depending on its own needs. Besides, each of these three models identifies 5 maturity levels: the initial process, the reproducible process, the defined process, the managed process, and the optimized process. Each maturity level consists of several attributes. Special attributes refer to specific process areas, general attributes (planning, information management, training and development) are the same for everyone. P3M3 provides that the transition to a new maturity level is possible only with direct participation in the development of organizational project management.

- IPMA Delta ${ }^{\circledR}$ Model (Project Excellence Model) was developed in 2009 by the International Project Management Association (IPMA). This model is based on international requirements to the competence of specialists (key performers - project managers, programs and portfolios, project participants, stakeholders, administrators, etc), projects (the focus of the assessment is on results, methods, tools) and organizations (assessment of the organizational competence in managing projects). IPMA Delta ${ }^{\circledR}$ define 5 maturity levels: Initial (level 1), Defined (level 2), Standardized (level 3), Managed (level 4), Optimized (level 5) (Bushuyev \& Wagner 2014; IPMA, 2015).

The studies (Backlund, Choronner, \& Sundqvist, 2014; PMI, 2018; PMI, 2020) show that organizations with a high project management maturity level complete projects more successfully and efficiently. In low-maturity organizations only $39 \%$ of projects get done on time; $46 \%$ are completed on budget; $56 \%$ meet the original intent or business purpose.

Most companies operating in the fields of IT and mass media have a high project management maturity level. However, the manufacturing companies or enterprises dealing with various activities in the public sector quite often have the lowest project maturity levels. It does not always depend on the share of the project component in the portfolio structure of the organizational activity. 
Niema, 2021. Implementation of Project Management Maturity Model to Improve the Efficiency of Activity of Local Self-Governments

The importance of assessing the maturity level and effective project management organization, in general, is emphasized, for example, by the published data of Hewlett Packard, AT\&T, IBM, Boeing, GM. They give evidence of the fact that following are the direct results of the implementation and improvement of project management processes:

- $\quad$ reduction by $30-65 \%$ of the project product receipt time;

- $\quad$ reduction by $35-75 \%$ of defects and spoilage in the course of project implementation;

- reduction of engineering corrections and changes in projects by 45$68 \%$;

- $\quad$ increase by $6 \%$ of the average profit indicator;

- $\quad$ the increase of investment profitability up to 20\% (Degtyarev, 2015).

To local self-government bodies, project development activities to make the best use of available resources and attract external resources are very important. Therefore, it is advisable to apply maturity models to them from the standpoint of effective project management. However, it is necessary to take into account the peculiarities of the project activities of local self-government bodies, the innovative component of local development projects and local managers' level of readiness to use the project management methodological support properly.

Many local self-government bodies are only instilling their project culture. This is confirmed, in particular, by the participants of the annual distance learning course called "Local Development Projects Management" on the platform of the Community of Practice: Sustainable Development (Spilnota praktyk, 2020). The course was initiated for the first time in 2012. On average, about half of the participants, taking the course in 2016-2020 indicated in the entrance questionnaire that they had no experience in project activities, $25 \%$ developed projects before, $4 \%$ of participants - managed projects. At the same time, the pace of implementation of the project approach in the activities of local self-government bodies is extremely high.

While forming an approach to assessing the current situation in the field of project activities of local self-government bodies, D. Bezuhlyi and Yu. Sharov suggest taking into account the degree of awareness of the action performed and the competence of staff related to project management. It includes:

- unconscious incompetence (a person does not know how to work properly, but does not even understand it);

- conscious incompetence (a person begins to understand that the work is performed without proper competence, the need for training is formed); 
- conscious competence (a person realizes that there is a field of activity that he or she understands / knows how to do and tries to act according to the rules);

- conscious competence (getting into a situation, a person suddenly finds out that he or she understands / knows how to do what he or she has not done before;

- regular practice of correct actions brings a person to a level of professionalism when you no longer need to think about individual operations and their sequence, many actions are performed automatically, and - correctly) (Bezuhlyi \& Sharov, 2015).

Taking into account this, as well as the state of methodological support of the project activity, at this stage a three-level model can be applied, with certain criteria for assigning the local self-government body to an appropriate level (Fig.1). The entry of the local self-government body to a high level of project maturity allows to reduce the negative impact of the human factor and, in a consistent manner, focus activities on meeting the needs of the territorial community on a project basis.

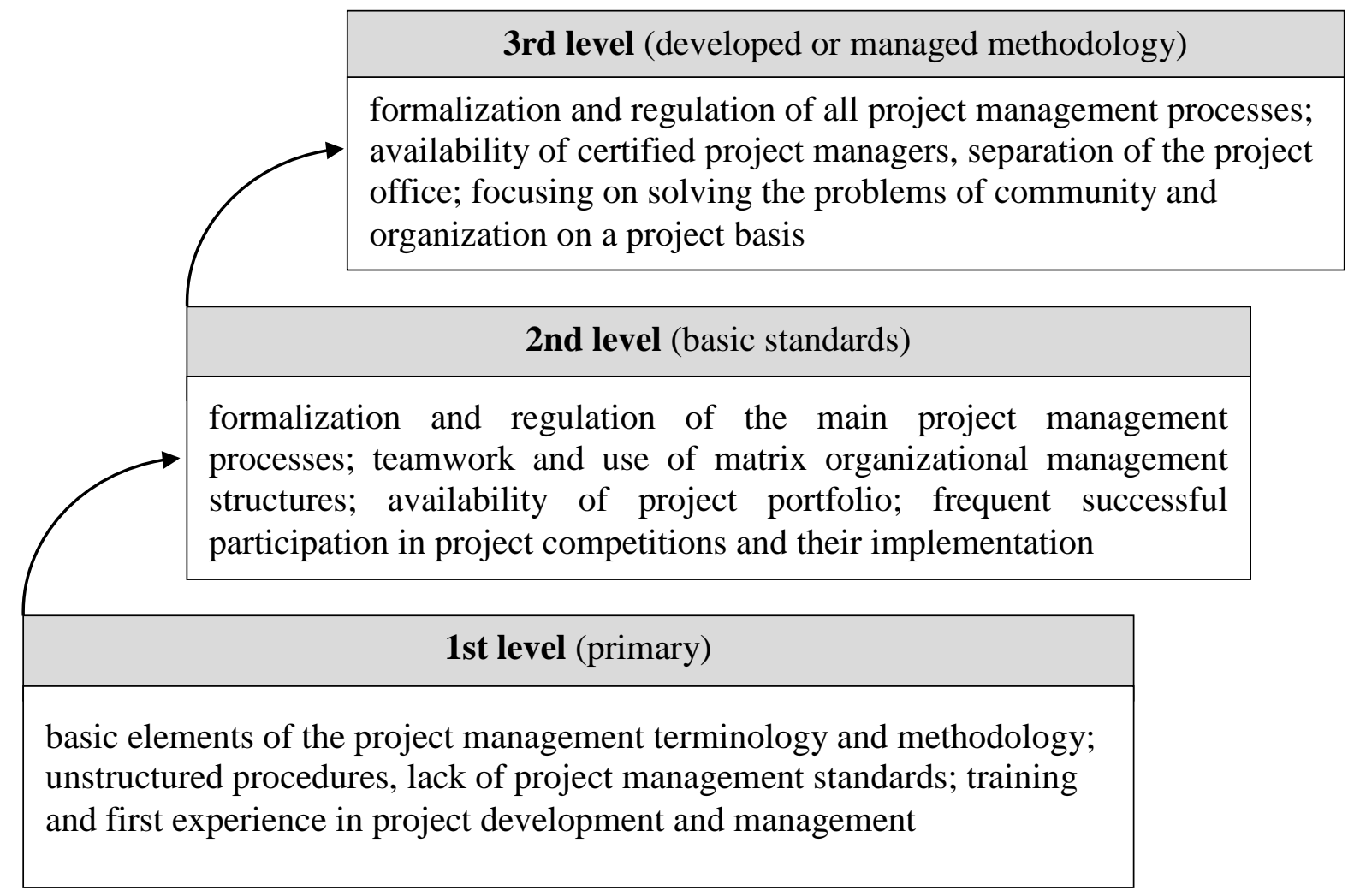

Figure 1 Maturity Model of Local Self-government

(suggested by the author) 
Niema, 2021. Implementation of Project Management Maturity Model to Improve the Efficiency of Activity of Local Self-Governments

The first level of the local self-government body maturity model (primary) is characterized by the fact that the project competencies of management staff are almost absent. The success and quality of project activities are mainly determined by individual knowledge and skills of the staff members (accidental success is possible, which is based on empirical knowledge of individual projects).

The second level (basic standards) is determined by the fact that the main processes are formalized by national regulatory documents and regulated by job descriptions. Teamwork and matrix control schemes are used. The staff members of the local self-government body generally use basic project management knowledge and skills, but this is not always done competently and systematically enough (procedures for developing and managing certain projects may sometimes deviate from the adopted basic standards). At the same time, the preparation of complex projects often requires the involvement of external consultants.

The third level of the model (developed or level of managed methodology) is the highest maturity level and it is characterized by formalization and regulation of all major project management processes, professional mastery of project management terminology and methodology, regular and effective use of teamwork, proper documentation and archiving of project activities, presence of certified project managers and the separation of the project office (either real or virtual), continuous further training of the staff members of the local selfgovernment body, regular victories in various project competitions, obtaining grant funding. This level is characterized by continuous improvement and approximation to project-oriented activities.

\section{Conclusions}

Consequently, the introduction of the maturity model provides an opportunity for the institution to choose an adequate strategy for processes improvement in the relevant field, helps to create a methodological basis for the improvement of the overall activity. Assessing the project manage ment maturity level of a local self-government body (primary level, level of basic standards or level of managed methodology) allows determining the degree of its readiness for effective management of activity and development based on the project approach. The entry of the local self-government body to a high level of project maturity will reduce the negative impact of the human factor, systematically focus activities on meeting the needs of the community on a project basis, improve the quality of project management processes, and reduce unproductive costs, etc. 
Professional development and staff training are important factors in the success of this process.

\section{References}

Backlund, F., Choronner, D., \& Sundqvist, E. (2014). Project Management Maturity Models A Critical Review. A case study within Swedish engineering and construction organizations. 27th IPMA World Congress. Procedia - Social and Behavioral Sciences, 119, 837-846. DOI: https://doi.org/10.1016/j.sbspro.2014.03.094

Bezuhlyi, D. H., \& Sharov, Yu. P. (2015). Pidkhid do otsiniuvannia rivnia proektnoi zrilosti orhaniv mistsevoho samovriaduvannia. Aspekty publichnoho upravlinnia, 3, 11-12, 89-97.

Bushuyev, S., \& Wagner, R. (2014). IPMA Delta ${ }^{\circledR}$ and IPMA Organisational Competence Baseline (OCB): new approaches in the field of project management maturity. International Journal of Managing Projects in Business, Vol. 7, 2, 1-12.

Cooke-Davies, T., Schlichter, J., \& Bredillet, C. (2001). Beyond the PMBOK® guide. Paper presented at Project Management Institute Annual Seminars \& Symposium, Nashville, TN. Newtown Square, PA: Project Management Institute. Retrieved from https://www.pmi.org/learning/library/organizational-model-maturity-body-knowledge7822

Degtyarev, M. A. (2015). Proektnaya zrelost i tsennostno-orientirovannoe upravlenie proektami. Retrieved from http://www.i-mash.ru/materials/economy/print:page,1,64 524-proektnaja-zrelosti-cennostno-orientirovannoe.html

Dziubina, A. V. (2010). Model zrilosti upravlinnia proektamy dlia vitchyznianykh pidpryiemstv. Visnyk Natsionalnoho universytetu «Lvivska politekhnika», 6, 235-239.

Grant, K. P., \& Pennypacker, J. S. (2006). Project management maturity: an assessment of project management capabilities among and between selected industries. IEEE Transactions on Engineering Management, 53(1), 59-68.

IPMA. (2015). IPMA Delta - moving organizations forward in translating strategy into results. Retrieved from https://www.ipma.world/assets/ IPMA_Delta_Brochure_ ENG_2015_Screen.pdf

Kertsner, G. (2003). Strategicheskoe planirovanie dlya upravleniya proektami s ispolzovaniem modeli zrelosti. M.: Kompaniya AyTi; M.: DMK Press, 320.

Malinina, M. V. (2011). Sovremennye modeli zrelosti organizacionnogo upravlenija proektami. Upravlenie proektami i programmami, 03(27), 228-239.

OGC. (2010). Portfolio, Programme and Project Management Maturity Model (P3M3). Version 2.1. Office of Government Commerce (OGC). Retrieved from http://miroslawdabrowski.com/downloads/P3M3/OGC\%20branded/P3M3_v2.1_Introd uction_and_Guide.pdf.

PMI. (2013). Organizational Project Management Maturity Model (OPM3®) - Third Edition. Knowledge Foundation. Newtown Square, PA: Project Management Institute (PMI), 205.

PMI. (2018). Pulse of the Profession ${ }^{\circledR}$ : Success in Disruptive Times. 10th Global Project Management Survey. Newtown Square, PA: Project Management Institute (PMI), 9.

PMI. (2020). Pulse of the Profession ${ }^{\circledR}$ : Ahead of the Curve: Forging a Future - Focused Culture. Report. Newtown Square, PA: Project Management Institute (PMI), 5.

Spilnota praktyk: Stalyi rozvytok. (2020). Retrieved from http://udl.despro.org.ua/ 
Niema, 2021. Implementation of Project Management Maturity Model to Improve the Efficiency of Activity of Local Self-Governments

Ushakova, A., \& Sharov, Yu. (2018). Vymiriuvannia y otsiniuvannia proektnykh kompetentnostei chleniv obiednanykh terytorialnykh hromad. Derzhavne upravlinnia ta mistseve samovriaduvannia, 3(38), 164-169. 